\title{
Games Edukatif Berbasis Android untuk Meningkatkan Kemampuan Mengenal Angka Anak Usia Dini
}

\author{
Yeni Solfiah $^{1^{凶}}$, Hukmi $^{2}$, Febrialismanto $^{3}$ \\ Pendidikan Guru Pendidikan Anak Usia Dini, Universitas Riau, Indonesia(1) \\ DOI: $10.31004 /$ obsesi.v6i3.910
}

\begin{abstract}
Abstrak
Penelitian ini memiliki tujuan untuk menciptakan games edukatif berbasis android dalam rangka meningkatkan kemampuan mengenal angka untuk anak. Metode yang digunakan dalam penelitian ini adalah riset dan pengembangan. Subjek penelitian merupakan anak usia 5-6 tahun yang berada di TK Pembina 3, TK Pembina 1 dan TK Babussalam di Kota Pekanbaru. Sampel dalam riset ini merupakan anak usia dini yang dipilih berdasarkan kriteria sesuai dengan kebutuhan penelitian. Data yang dikumpulkan melalui lembar validasi dari ahli materi, media dan guru TK serta pre-test dan post-test mengenai kemampuan mengenal angka setelah menggunakan games edukatif. Teknik pengumpulan data yang digunakan dengan metode observasi. Data yang terkumpul dianalisis secara kualitatif dan kuantitatif. Hasil riset mengungkapkan bahwa games edukatif berbasis android teruji meningkatkan kemampuan mengenal angka. Berdasarkan hasil validasi ditemui bahwa games edukatif ini memiliki kelayakan. Kebaruan yang ditemui dalam riset ini adalah pentingnya meningkatkan kemampuan mengenal angka melalui pemanfaatan kemajuan teknologi informasi dalam bentuk games edukatif.
\end{abstract}

Kata kunci: games edukatif; kemampuan mengenal angka; anak usia dini

\begin{abstract}
This research was designed to create android based educational games with the aim of increasing children's ability to recognize numbers. Research and development were the method used in this study. Subjects were selected from 5 to 6-year-old students from Pembina 3 Kindergarten, Pembina 1 Kindergarten, and Babussalam Kindergarten in Pekanbaru city. The subjects selected for this research met the criteria set forth in the research requirements. The data were collected from validated response sheets provided by experts in materials, media and kindergarten teachers as well as pre-test and post-test responses on number recognition ability after utilizing the educational games. The data collected were analyzed qualitatively and quantitatively. Android-based educational games give impact on the number recognition capability in $72.63 \%$ of the children. The novelty displayed in this research is that it is important that the ability to recognize numbers be improved through the utilization of advances in information technology in the form of educational games.
\end{abstract}

Keywords: educational games; number recognition ability; young children

Copyright (c) 2021 Putu Indah Lestari, Elizabeth Prima

$\triangle$ Corresponding author:

Email Address: yeni.solfiah@lecturer.unri.ac.id (Riau, Indonesia)

Received 23 November 2020, Accepted 12 March 2021, Published 30 December 2021 


\section{PENDAHULUAN}

Anak usia dini ialah individu yang sedang mengalami masa pertumbuhan dan perkembangan yang paling signifikan jika dibandingkan dengan tahapan yang lainnya. Sejalan dengan hal tersebut maka Montessori dalam (Gutex, 2013) periode ini disebut sebagai masa emas dan tidak akan terulang untuk kedua kalinya dalam rentang kehidupan manusia. Dengan demikian dapat digambarkan bahwa pada era ini seluruh spek perkembangan sedang berada dalam masa peka yang akan menjadi pondasi untuk tahap selanjutnya. Oleh karena itu, menjadi sangat penting bagi orang tua dan guru untuk memanfaatkan peluang ini demi tercapainya optimalisasi potensi anak. Untuk mencapainya maka diperlukan stimulasi melalui proses pembelajaran baik di rumah maupun di sekolah dan melalui aktivitas yang menyenangkan dan memanfaatkan kemajuan teknologi informasi.

Anak usia dini dengan mudah menemukan angka di lingkungan sekitarnya baik itu dalam bentuk simbol maupun konsep. Tidak mengherankan jika sebagian anak usia dini sudah mulai mengenal dan belajar angka sebelum memasuki pendidikan formal di sekolah (Mou, Zhang, Piazza, \& Hyde, 2021). Pengalaman dan kesempatan untuk mengenal angka dapat ditempuh melalui kegiatan bermain sambil belajar. Masa ini dipandang sebagai tahapan yang sangat fundamental untuk membangun pengetahuan dan kemampuan mengenal angka serta akan menentukan pencapaian hasil belajar matematika di jenjang pendidikan selanjutnya (Ramani, Daubert, \& Scalise, 2019). Dengan kata lain, perolehan kapabilitas yang berkaitan dengan angka menempati posisi yang strategis bagi anak di masa yang akan datang.

Sebagai seorang peserta didik, anak dipandang perlu untuk mengembangkan kemampuan mengenal angka baik di lingkungan rumah maupun di sekolah (Reys, Robert.E, 2017). Kehadiran angka yang sangat mudah ditemukan di lingkungan sekitar anak mengharuskan penguasaan yang baik terhadapnya. Seperti contoh mengetahui tanggal ulang tahun, menyanyikan lagu, jumlah halaman pada buku cerita, nomor rumah, loker di sekolah serta nomor telepon. Dapat dideskripsikan bahwa anak usia dini dapat menggunakan angka secara alamiah di dalam kehidupan sehari-harinya (Kennedy, Tipps, \& Johnson, 2008).

Kemampuan anak dalam mengenal angka menjadi penting karena berbagai pekerjaan profesional memerlukan keahlian yang baik di dalamnya (Rotem \& Henik, 2020). Seperti guru, pilot, chef, dosen, peneliti, arsitek dan sebagainya. Untuk dapat mencapai cita-cita tersebut maka anak usia dini sebaiknya mendapatkan kesempatan yang baik dalam mengembangkan kemampuan mengenal angka. Oleh karena itu, orangtua dan guru diharapkan mampu menciptakan kesempatan melalui pemanfaatan berbagai sumber belajar. Seperti balok, puzzle, story telling, lembar kerja anak, buku cerita bergambar serta games edukatif berbasis kemajuan teknologi.

Salah satu inovasi yang dapat digunakan oleh guru dan orang tua dalam rangka meningkatkan kemampuan mengenal angka anak adalah dengan menggunakan kemajuan teknologi yang sedang berkembang pesat saat ini. Pemanfaatan teknologi memiliki peran yang strategis dalam proses pembelajaran untuk meningkatkan kemampuan mengenal angka (NCTM, 2000). Games edukatif memberikan pengalaman yang melibatkan anak untuk terlibat antusias dan mampu meningkatkan pembelajaran aktif (Pei \& Zhang, 2019). Selain itu, anak dapat mengembangkan kemampuannya tanpa adanya batasan waktu dan tempat. Artinya dengan menggunakan games ini, anak dapat bermain dimana pun dan kapan pun selama masih dalam pengawasan guru dan orang tua.

Seiring dengan perkembangan zaman, maka cara anak untuk mendapatkan ilmu pengetahuan juga mengalami perubahan yang pesat jika dibandingkan dengan era beberapa dekade yang lalu (Gewati, 2018). Jika generasi terdahulu hanya dapat menggunakan spidol dan whiteboard di dalam kelasnya. Sebaliknya sosok anak usia dini yang terkini sangat akrab menggunakan teknologi seperti tablet atau smartphone baik di rumah maupun di sekolah (Behnamnia, Kamsin, Akmar, Ismail, \& Hayati, 2020). Kondisi ini juga mempengaruhi bagaimana cara anak untuk bermain dan belajar berbagai konsep dan simbol angka. Guru dan 
orang tua diharapkan mampu mengikuti peralihan tersebut sehingga pembelajaran yang dilaksanakan di sekolah dan di rumah menjadi relevan dengan kebutuhan anak.

Seiring dengan kemajuan teknologi informasi dan komunikasi, maka kebaruan ini juga memberi sumbangan yang positif bagi dunia pendidikan. Termasuk dalam proses pembelajaran matematika, yang merupakan konsep penting dalam mendukung kompetensi anak. Seperti yang disampaikan oleh (Moyer-Packenham et al., 2019) bahwa games digital mendukung pengalaman anak dalam pembelajaran matematika. Pembelajaran matematika yang menggunakan aplikasi digital memberikan kesempatan anak untuk terlibat aktif memecahkan permasalahan, memperoleh umpan balik yang cepat dan berada dalam situasi yang nyata. Manfaat lain dari game edukatif menurut (Vanbecelaere et al., 2020) adalah mampu meningkatkan hasil belajar matematika dan membaca pada anak. Dengan kata lain game sangat efektif jika digunakan sebagai media dan sumber belajar dalam pembelajaran.

Namun sebagian anak usia dini kurang mendapat kesempatan untuk berlatih dan meningkatkan keterampilan mengenal angka (Aunio et al., 2019). Seperti yang disampaikan oleh (Spaull \& Kotze, 2015) bahwa anak usia dini memiliki kesempatan serta kompetensi yang rendah dalam mengenal angka. Hal ini secara langsung berdampak kepada rendahnya penguasaan anak dalam menyelesaikan permasalahan sederhana yang berkaitan dengan angka dengan persentase sekitar 5\% (Bassok \& Latham, 2016). Hal ini sejalan dengan pernyataan (Litkowski, Duncan, Logan, \& Purpura, 2020) bahwa proses pembelajaran angka di jenjang pendidikan anak usia dini cenderung tidak didukung oleh kompetensi guru. Sejalan dengan kondisi tersebut maka dapat digambarkan bahwa terdapat kesenjangan yang dihadapi di sekolah dalam hal pengenalan angka bagi anak. Selanjutnya pada studi Programme for International Student Assessment (PISA) dapat digambarkan bahwa rata-rata kemampuan matematika anak di Indonesia masih dalam kategori rendah jika dibandingkan dengan negara lain yang ada di kawasan Asia Tenggara. Rincian perolehan skor matematika pada Studi PISA yang diperoleh oleh Indonesia terlihat jelas pada Tabel 1 (Pratiwi, 2019).

Berdasarkan uraian data perolehan skor matematika dalam studi PISA dapat digambarkan bahwa kemampuan siswa di Indonesia dalam menyelesaikan permasalahan matematika masih perlu diperbaiki (Tohir, 2019). Data ini menggambarkan kemampuan anakanak di Indonesia perlu menjadi perhatian banyak pihak, baik sekolah, pemerintah, guru dan orang tua. Rangking yang diperoleh menunjukkan bahwa proses pembelajaran matematika yang selama ini dijalankan perlu adanya inovasi yang akan menjawab kebutuhan anak dalam rangka meningkatkan kemampuannya (Setyanti, 2017).

Tabel 1. Perolehan Skor Matematika dalam PISA

\begin{tabular}{lll}
\hline No. & Tahun Pelaksanaan & Rangking Indonesia \\
\hline 1. & 2000 & 39 dari 41 negara peserta \\
2. & 2003 & 38 dari 40 negara peserta \\
3. & 2006 & 50 dari 56 negara peserta \\
4. & 2009 & 61 dari 65 negara peserta \\
5. & 2012 & 64 dari 65 negara peserta \\
6. & 2015 & 64 dari 69 negara peserta \\
7. & 2018 & 73 dari 79 negara peserta \\
\hline
\end{tabular}

Bagi sebagian anak, bermain dan belajar mengenal angka merupakan hal yang sulit jika dibandingkan dengan kegiatan yang lain (Tezer \& Cumhur, 2016). Konsep angka yang abstrak membuatnya sulit untuk dikenali sehingga tidak mengherankan jika aktivitas pembelajarannya menjadi momok tersendiri. Selain itu, keterbatasan sumber belajar seperti alat permainan edukatif dan penggunaan teknologi membuat anak semakin tidak tertarik mengenal angka. Kondisi ini didukung oleh kemampuan mengajar matematika guru yang kurang memadai (Solfiah, 2018). Kurangnya fasilitas, kesempatan dan kompetensi guru menambah minimnya kemampuan anak untuk mengembangkannya. 
Adapun tujuan dari penelitian ini adalah untuk menciptakan games edukatif berbasis android untuk meningkatkan kemampuan mengenal angka anak usia dini. Secara empiris tujuan riset adalah untuk mendeskripsikan pengembangan dan kelayakan media games edukatif berbasis android dalam mendukung kemampuan mengenal angka di TK Pembina 1, TK Pembina 3 dan TK Babussalam di Pekanbaru, Provinsi Riau.

\section{METODOLOGI}

Metode dalam penelitian ini adalah research and development ( $R$ \& $D)$ yang menggunakan analisis data secara kualitatif dan kuantitatif. Tahapan yang telah dilalui dalam penelitian ini menggunakan model (Sugiyono, 2017) yang terdiri dari beberapa langkah, di antaranya adalah: 1) mengetahui masalah dan/atau potensi, 2) pengumpulan data, 3) desain produk, 4) validasi desain, 5) revisi desain, 6) pembuatan produk, 7) uji coba lapangan terbatas, 8) revisi produk, 9) uji lapangan utama, 10) revisi produk, 11) uji coba operasional, 12) revisi produk, 13) disseminasi/produksi massal. Adapun langkah-langkah pengembangan dapat dilihat pada gambar 1.

Penelitian ini berlangsung di TKN Pembina 1 dan 3 serta TK Babussalam yang berlokasi di Kota Pekanbaru, Provinsi Riau. Untuk mendapatkan data uji coba terbatas tim peneliti menetapkan 11 anak sebagai responden uji lapangan terbatas dan 30 anak sebagai responden uji lapangan utama yang berasal dari tiga sekolah yang berbeda. Kriteria yang ditentukan dalam pemilihan responden berdasarkan tingkat kemampuan anak di dalam kelas seperti kelompok anak yang memiliki kemampuan paling baik, sedang dan paling bawah. Dalam rangka mengumpulkan data maka tim peneliti menggunakan lembar validasi games edukatif yang disebar kepada ahli media, ahli materi dan guru TK, lembar observasi minat anak terhadap games edukatif serta lembar observasi kemampuan mengenal angka anak.

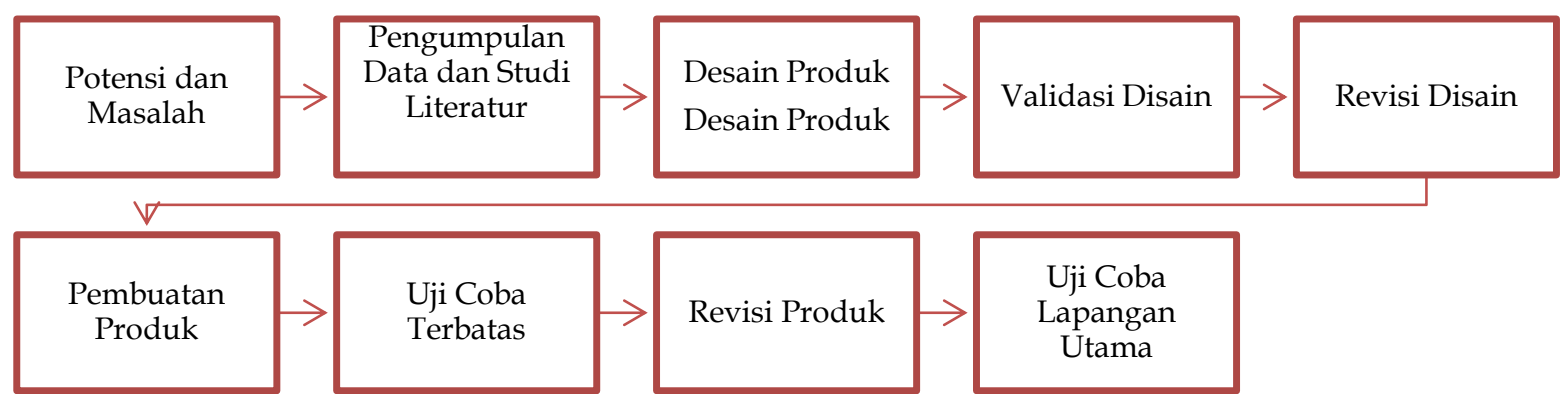

Gambar 1. Tahapan Penelitian

Data yang dikumpulkan pada riset ini terdiri dari data sekunder. Hal ini karena sebagian besar anak sedang mengalami BDR (Belajar dari Rumah) selama pandemi Covid-19, sehingga tidak memungkinkan adanya proses observasi secara langsung. Sumber data sekunder didapat dari observasi kemampuan mengenal angka yang diperoleh dari hasil pengamatan guru (pre-test). Untuk mendapatkan data post-test diperoleh dari pemantauan orangtua setelah anak mendapat perlakuan yakni games edukatif berbasis android yang diberikan oleh guru ke dalam grup Whatsapp kelas.

Teknik pengumpulan data dalam studi ini adalah teknik observasi, angket dan dokumentasi. Adapun teknik observasi dilakukan dengan mengamati anak dalam menuntaskan kegiatan bermain games edukatif yang bertujuan meningkatkan kemampuan mengenal angka. Selanjutnya teknik angket diberikan kepada ahli media, materi serta guru TK . Lembar validasi untuk ahli media bertujuan untuk mengukur kevalidan games edukatif berbasis android. Skala yang dihitung adalah skala sikap yang memiliki rentang penilaian 15, dengan uraian sebagai berikut: sangat baik (5), baik (4), cukup baik (3), kurang baik (2) dan sangat kurang baik (1). Lembar validasi untuk ahli materi (matematika) bermaksud mengukur kevalidan produk. Riset ini juga menggunakan dokumentasi sebagai salah satu teknik 
pengumpulan data dalam bentuk foto anak yang sedang memainkan games edukatif di rumah dengan pendampingan orang tua.

\section{HASIL DAN PEMBAHASAN}

Tim peneliti telah menghasilkan produk berupa games edukatif berbasis android dalam rangka meningkatkan kemampuan mengenal angka bagi anak usia dini di Kota Pekanbaru, Provinsi Riau. Latar belakang dipilihnya Provinsi ini berdasarkan data dari Pusat Penilaian Pendidikan (Kementerian Pendidikan dan Kebudayaan, 2018) menjabarkan bahwa hasil Ujian Nasional pada bidang studi matematika khususnya penguasaan angka masih tergolong rendah jika dibandingkan dengan Provinsi lainnya. Selanjutnya berdasarkan data dari (Kementerian Pemberdayaan Perempuan dan Perlindungan Anak, 2019) diketahui bahwa jumlah populasi anak yang terbanyak terdapat di Provinsi Riau.

Tahapan dari penelitian games edukatif berbasis android untuk meningkatkan kemampuan mengenal angka terdiri dari; kreasi 1, kreasi 2, kreasi 3, dan kreasi terakhir.

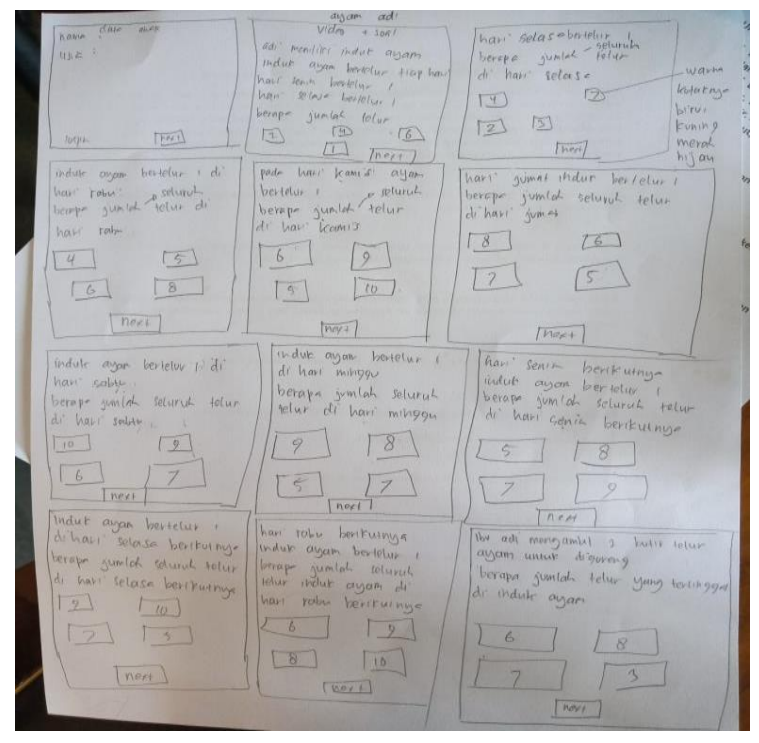

Gambar 2 Kreasi ke-1 Games Edukatif Berbasis Android

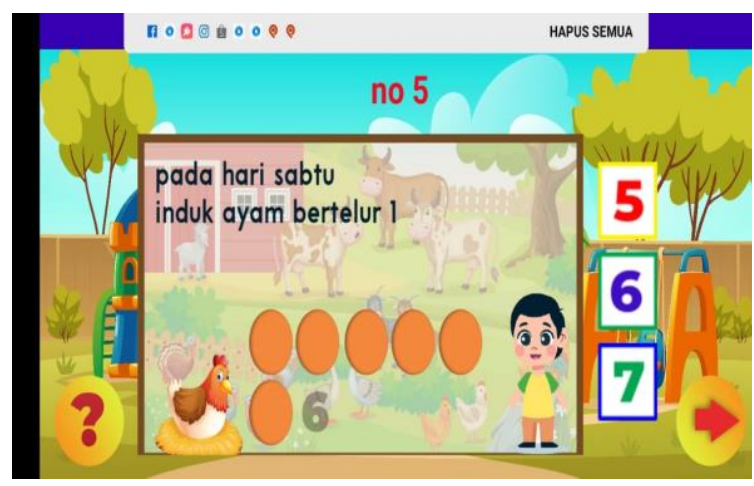

Gambar 4. Kreasi ke-3 Games Edukatif Berbasis Android

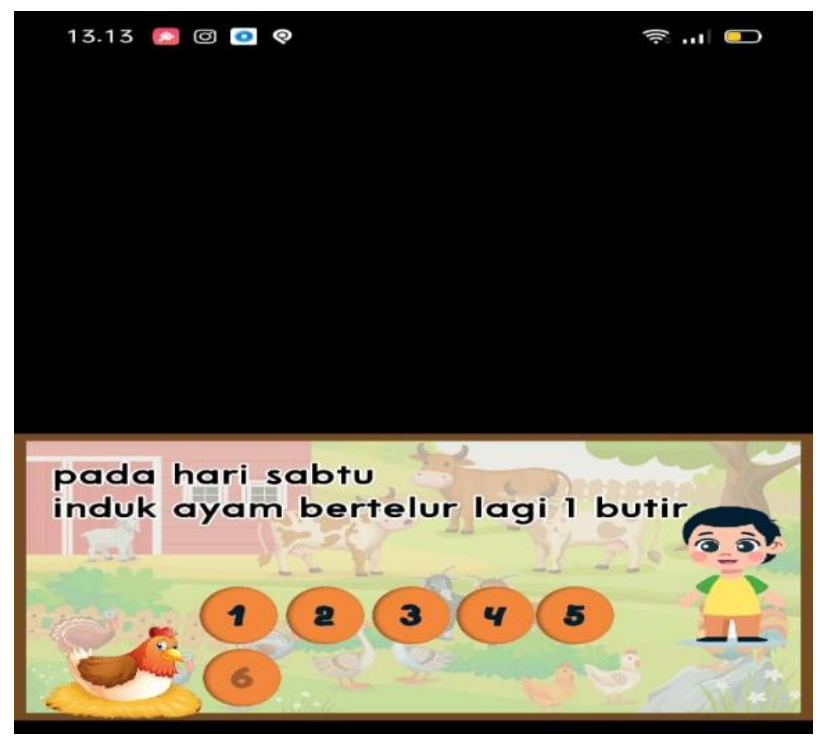

Gambar 3. Kreasi ke-2 Games Edukatif Berbasis Android

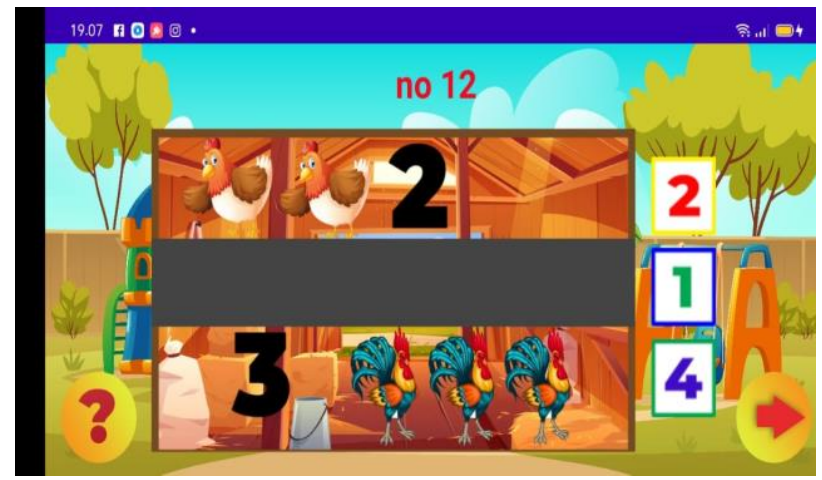

Gambar 5 Kreasi ke-4 Games Edukatif Berbasis Android

\section{Kreasi 1}

Produk dari riset ini diperoleh dari hasil observasi dan analisis keperluan di lapangan dan studi kepustakaan dan dilaksanakan hingga membentuk kreasi 1 yang merupakan desain awal games edukatif berbasis android. Pada kreasi 1, desain produk masih berbentuk tulisan tangan dari tim peneliti. Kemudian rancangan 1 didiskusikan dengan dua orang pakar 
(Materi dan Media) sehingga menghasilkan rancangan 2 yang berbentuk games edukatif dengan menggunakan aplikasi adobe photoshop sama adobe illustrator. Lebih jelasnya dapat dilihat pada gambar 2.

\section{Kreasi 2}

Hasil produk pada kreasi 2 ini diberikan kepada uji coba kelompok kecil yang berjumlah 11 anak. Setelah itu tim peneliti melaksanakan perbaikan dan hal ini akan menjadi informasi penting untuk tahapan kreasi 3. Adapun kekurangan yang ditemui pada tahapan ini adalah munculnya simbol dan konsep angka dalam waktu yang bersamaan di dalam gambar telur. Perbaikan dilakukan dengan menghilangkan simbol angka pada gambar telur agar anak lebih mudah memahami konsep angka melalui jumlah gambar telur dan menghubungkannya dengan symbol angka yang muncul selanjutnya. Adapun hasil dari kreasi 2 adalah seperti yang terdapat pada gambar 3.

\section{Kreasi 3}

Pengembangan kreasi 3 dilakukan dengan uji coba kelompok besar pada 30 anak usia 5-6 tahun, setelah itu dilaksanakan peninjauan yang akan menjadi rancangan akhir untuk uji efektifitas games edukatif berbasis android. Adapun perbaikannya seperti menghilangkan simbol angka yang muncul pada setiap gambar telur. Jika pada kreasi 2, setiap gambar telur diberi simbol angka namun pada tahapan ketiga ini setiap gambar telur tidak memiliki simbol tetapi hanya ada satu simbol angka yang mewakili jumlah keseluruhan telur. Menurut ahli materi bahwa tahapan belajar angka anak masih berada pada tahapan enaktif, maka tim peneliti menggantinya sesuai dengan yang ada pada Gambar 4.

\section{Kreasi Terakhir}

Hasil pengembangan games edukatif berbasis android meghasilkan rancangan final untuk dilanjutkan pada uji efektifitas. Pada rancangan final ini, tim peneliti memperbarui tampilan gambar sehingga tidak monoton. Hal ini berdasarkan saran dari ahli media, karena pada kreasi ke-3 gambar dan audio yang muncul cenderung sama pada setiap bagian. Adapun revisi tersebut dapat dilihat pada Gambar 5.

Games edukatif ini sudah tersedia di Play Store sehingga memudahkan orang tua dan guru untuk mengaksesnya di mana saja dan kapan pun. Setelah selesai memainkan games ini, anak juga akan mengetahui skor yang diperoleh dari aktivitas bermain yang sudah dilakukannya. Anak dapat bermain secara mandiri dengan mengikuti setiap bagian mulai dari tampilan awal sampai pada skor akhir yang menunjukkan kemampuan anak dalam mengenal angka. Jika anak belum mencapai skor yang diinginkan maka dapat mengulang kembali permainan sesuai dengan kebutuhan dan minat. Tampilan awal Games Edukatif Berbasis Android dapat dilihat pada gambar 6.

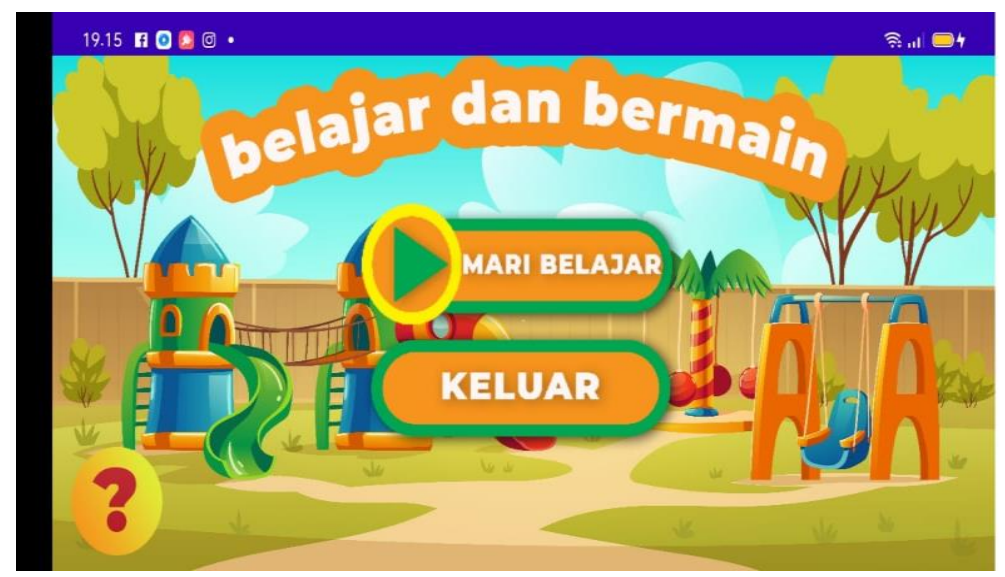

Gambar 6 Tampilan Awal Games Edukatif Berbasis Android 


\section{Uji Kelayakan Games Edukatif Berbasis Android \\ Uji Validitas Ahli}

Penelitian ini melibatkan ahli materi (matematika didaktis), media pembelajaran anak usia dini dan guru TK. Setiap komponen dalam produk divalidasi oleh validator yang memiliki latar belakang pendidikan dan keahlian di bidang yang sesuai dengan kebutuhan riset. Terdapat sepuluh item pertanyaan yang diajukan kepada para ahli seperti: (1) kesesuaian materi dengan kompetensi dasar, (2) kesesuaian dan kejelasan isi materi, (3) petunjuk belajar, (4) kemenarikan penyajian materi, (5) kejelasan contoh yang diberikan, (6) tingkat kesulitan pertanyaan, (7) bahasa yang digunakan mudah dipahami, (8) kemudahan petunjuk pertanyaanperan aktif anak dalam aktivitas belajar, (9) peran aktif anak dalam aktivitas belajar dan (10) memberi kesempatan anak untuk berlatih secara mandiri. Setelah para ahli mengisi lembar validasi maka data diolah dengan menghitung frekuensi jawaban. Setiap jawaban akan dikaitkan dalam bentuk pernyataan dari para ahli dengan rentang skor yang tersedia dari 1 sampai 5. Penjelasannya dapat dilihat pada Tabel 2.

Tabel 2. Persentase Validasi Ahli

\begin{tabular}{llccc}
\hline No. & Ahli & Hasil Angket & Persentase & $\begin{array}{l}\text { Keterangan } \\
\text { Kelayakan Media }\end{array}$ \\
\hline $\mathbf{1}$ & Materi & $44 / 50 \times 100 \%$ & $88 \%$ & Sangat layak \\
$\mathbf{2}$ & Media Pembelajaran & $50 / 55 \times 100 \%$ & $90,91 \%$ & Sangat layak \\
$\mathbf{3}$ & Guru Profesional & $422 / 500 \times 100 \%$ & $84,40 \%$ & Sangat layak \\
\hline
\end{tabular}

Berdasarkan Tabel 2 di atas maka dapat digambarkan bahwa games edukatif berbasis android sangat layak dengan nilai $87,77 \%$. Selanjutnya para ahli yang dilibatkan dalam studi ini juga memberikan masukan membangun yang diberikan dalam bentuk kualitatif. Berdasarkan informasi tersebut maka tim peneliti melakukan revisi sesuai saran dari ahli.

\section{Uji Empiris}

Uji empiris dilaksanakan dengan uji coba kelompok kecil di luar TKN Pembina 3, TKN Pembina 1 dan TK Babussalam. Selanjutnya setelah produk direvisi dua kali maka dilaksanakan uji coba kelompok besar dilakukan di tiga TK tempat tim peneliti mengambil data. Langkah ini bertujuan untuk uji efektifitas games edukatif berbasis android terhadap kemampuan mengenal angka responden.

\section{Hasil Pra Pengembangan}

\section{Minat Awal Anak Terhadap Games Edukatif Berbasis Android}

Produk dalam penelitian ini terlebih dahulu dilakukan uji lapangan terbatas pada 11 anak yang berusia 5-6 tahun di luar kelompok yang dijadikan sebagai uji lapangan utama. Pengambilan data ini berlangsung dengan observasi yang dilakukan oleh orangtua di rumah. Rentang skor yang diisi oleh orangtua mulai dari 1-5 dan hasil pengamatan minat tersebut terdapat pada Tabel 3 .

Menurut penjabaran Tabel 3, maka dapat digambarkan bahwa secara keseluruhan anak memiliki minat dan ketertarikan yang tinggi dalam bermain games edukatif tersebut. Terdapat tiga indikator pernyataan yang diisi oleh orangtua melalui observasi dengan hasil yang berada pada kategori sangat baik untuk pernyataan pertama dan ketiga serta kategori baik pada pernyataan kedua.

Berdasarkan hasil studi pendahuluan mengenai keadaan awal terkait kemampuan anak dalam mengenal angka ditemukan bahwa terdapat 9 anak yang berada pada kategori belum berkembang (BB), 15 anak dengan kategori mulai berkembang (MB) serta 6 anak yang berada di kategori berkembang sesuai harapan (BSH). Dengan kata lain bahwa kemampuan awal anak dalam mengenal angka masih rendah dengan pesentase $30 \%$ dengan kriteria belum berkembang (BB), 50\% anak masih berada pada kriteria mulai berkembang (MB) serta $20 \%$ 
anak dengan kriteria berkembang sesuai harapan (BSH). Data awal kemampuan anak dapat dilihat pada Tabel 4 .

Tabel 3: Data Minat Awal Anak Terhadap Games Edukatif

\begin{tabular}{llll}
\hline No. & Pernyataan & Persentase & Kategori \\
\hline $\mathbf{1}$ & $\begin{array}{l}\text { Adanya kemauan anak untuk melihat dan mengamati games edukatif } \\
\text { (anak hanya mengamati baik secara individu atau kelompok) }\end{array}$ & $89,09 \%$ & $\begin{array}{l}\text { Sangat } \\
\text { Baik }\end{array}$ \\
$\mathbf{2}$ & $\begin{array}{l}\text { Anak memperhatikan games edukatif (misalnya: perhatian pada isi } \\
\text { [gambar/tulisan/audio/video atau; menanyakan hal terkait isi dan }\end{array}$ & $78,18 \%$ & Baik \\
& $\begin{array}{l}\text { lainnya) } \\
\text { Anak menyukai games edukatif waktu digunakan oleh orangtua } \\
\text { dalam proses BDR (Belajar dari rumah) misalnya: memperhatikan } \\
\text { dalam penggunaan games edukatif; adanya respons yang sesuai } \\
\text { terhadap penggunaan games tersebut. }\end{array}$ & & Sangat \\
Jumlah & $84,24 \%$ & $\begin{array}{l}\text { Saik } \\
\text { Baik }\end{array}$ \\
\hline
\end{tabular}

Tabel 4: Data Kondisi Awal Kemampuan Mengenal Angka anak

\begin{tabular}{lrr}
\hline $\mathrm{N}$ & Valid & 30 \\
& Missing & 0 \\
Mean & & 10.1333 \\
Median & 10.0000 \\
Mode & 8.00 \\
Std. Deviation & & 2.33021 \\
Variance & 5.430 \\
Minimum & 5.00 \\
Maximum & 14.00 \\
Sum & 304.00 \\
\hline
\end{tabular}

Selanjutnya, ringkasan deskripsi data kondisi awal tersebut dikelola dalam distribusi frekuensi yang tertera pada Tabel 5

Tabel 5: Distribusi Frekuensi

\begin{tabular}{ccc}
\hline Rentang & Frekuensi Absolut & Frekuensi Relatif \\
\hline $4-5$ & 1 & $3,33 \%$ \\
$6-7$ & 1 & $3,33 \%$ \\
$8-9$ & 11 & $36,67 \%$ \\
$10-11$ & 10 & $33,33 \%$ \\
$12-13$ & 3 & $10 \%$ \\
$14-15$ & 4 & $13,33 \%$ \\
\hline Jumlah & $\mathbf{3 0}$ & $\mathbf{1 0 0} \%$ \\
\hline
\end{tabular}

Berdasarkan data kondisi awal kemampuan mengenal angka anak berada di bawah nilai rata-rata sejumlah 24 anak $(80 \%)$ sementara jumlah anak yang berada di atas kelas ratarata sebanyak 6 anak (20\%).

\section{Hasil Penerapan Games Edukatif Berbasis Android}

Penerapan dilakukan pada sekelompok anak berusia 5-6 tahun di TKN Pembina 1 dan 3 serta TK Babussalam dengan jumlah 30 anak. Hasil temuan lapangan diperoleh data hasil penilaian kemampuan mengenal angka selama dua minggu tatap muka daring dengan 6 kali tatap muka. Data hasil penilaian dalam skala interval yang mencakup perhitungan rerata, median, modus, nilai maksimum, nilai minimum, standar deviasi dan varians dapat dilihat 
pada Tabel 6. Selanjutnya, rangkuman deskripsi data informasi penilaian kemampuan mengenal angka disusun dalam tabel distribusi frekuensi pada Tabel 7.

Berdasarkan Tabel 7, maka dapat dilihat bahwa nilai rerata anak yang berada di atas nilai rata-rata sebanyak 26 anak atau $86,6 \%$; anak yang berada pada kelas rata-rata sebanyak 4 anak atau $13,3 \%$. Jika persentase kemampuan mengenal angka di atas dapat digambarkan dalam bentuk grafik batang pada gambar 7 dan 8 .

Berdasarkan hasil penilaian kemampuan mengenal angka anak yang menggunakan games edukatif android maka dapat disimpulkan bahwa 26 anak memiliki kategori berkembang sangat baik. Maknanya 86,3 \% anak memiliki kategori kemampuan berkembang sangat baik. Terdapat 4 anak yang berada pada kategori berkembang sesuai harapan. Artinya $13,3 \%$ anak mencapai kategori berkembang sesuai harapan.

Tabel 6: Data Hasil Penilaian Kemampuan Mengenal Angka Anak

\begin{tabular}{lrr}
\hline $\mathrm{N}$ & Valid & 30 \\
& Missing & 0 \\
Mean & & 17.3000 \\
Median & 17.0000 \\
Mode & $17.00^{\mathrm{a}}$ \\
Std. Deviation & 1.51202 \\
Variance & 2.286 \\
Minimum & 14.00 \\
Maximum & 20.00 \\
Sum & 519.00 \\
\hline
\end{tabular}

Tabel 7: Distribusi Frekuensi

\begin{tabular}{ccc}
\hline Rentang & Frekuensi Absolut & Frekuensi Relatif \\
\hline $13-14$ & 2 & $6,67 \%$ \\
$15-16$ & 6 & $20,00 \%$ \\
$17-18$ & 16 & $53,33 \%$ \\
$19-20$ & 6 & $20,00 \%$ \\
$21-22$ & 0 & $0,00 \%$ \\
$23-24$ & 0 & $0,00 \%$ \\
\hline Jumlah & $\mathbf{3 0}$ & $\mathbf{1 0 0} \%$ \\
\hline
\end{tabular}

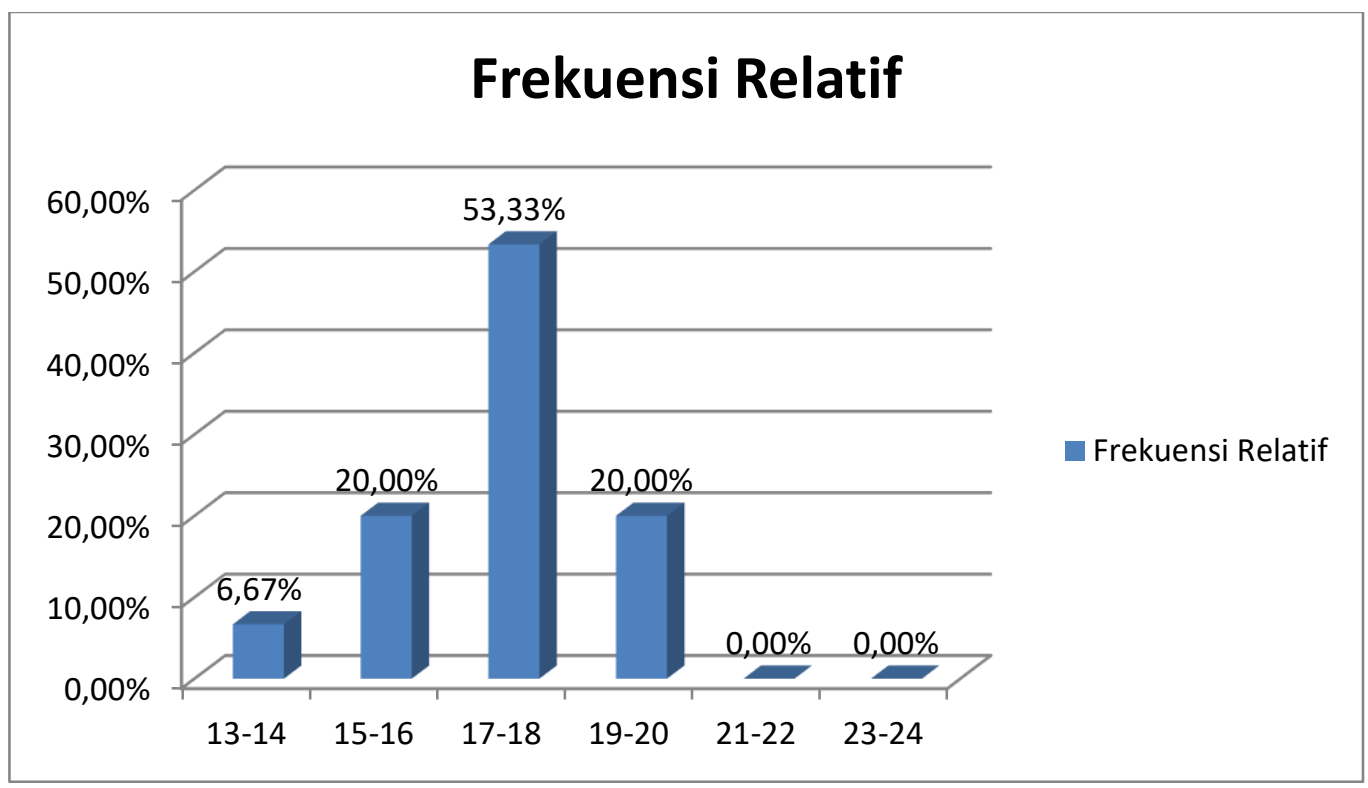

Gambar 7 Grafik Frekuensi Absolut 


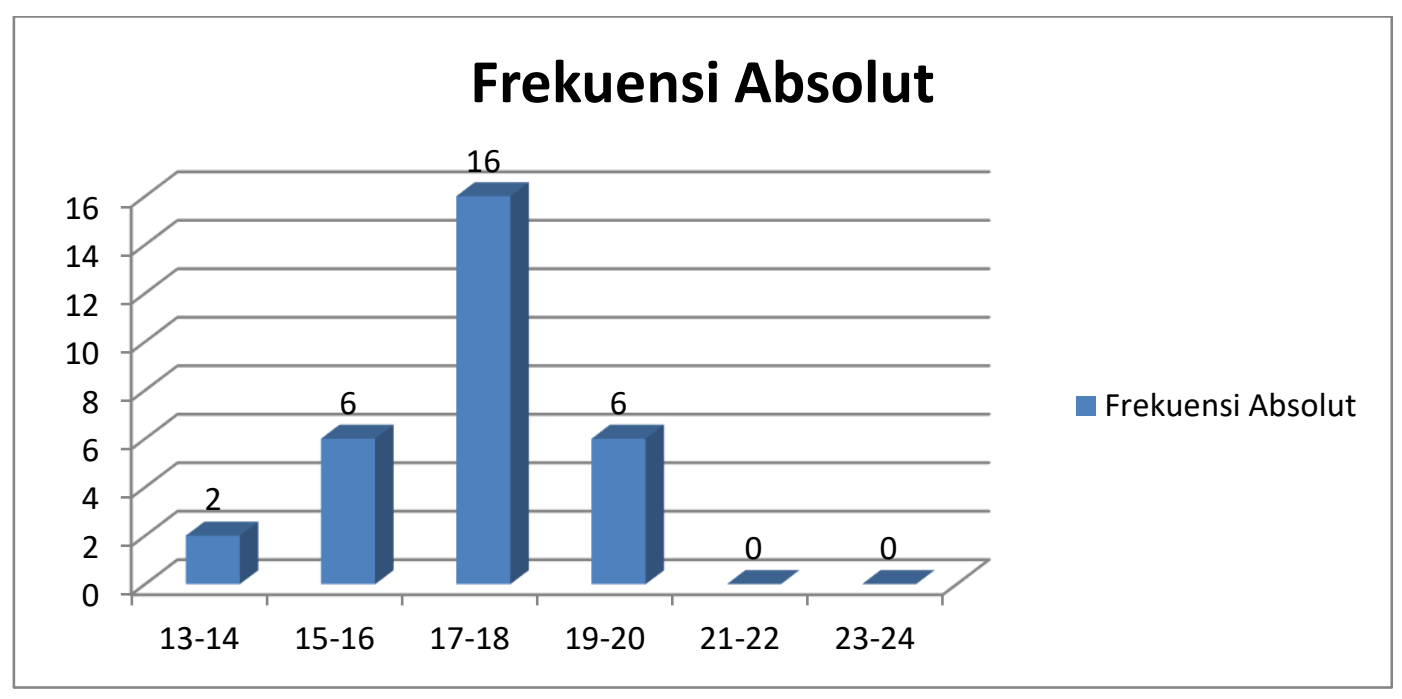

Gambar 8 Grafik Frekuensi Absolut

Tabel 8: Data Nilai Rata-rata Sebelum dan Sesudah Penerapan Games Edukatif Berbasis Android

\begin{tabular}{ccccccc}
\hline Kegiatan & N & Rata-rata & Standar Deviasi & Nilai $\mathbf{t}$ hitung & df & T tabel \\
\hline Sebelum & 30 & 10,13 & 2,33 & 17,86 & 29 & 2,042 \\
Sesudah & 30 & 17,3 & 1,51 & & 29 & \\
\hline
\end{tabular}

Berdasarkan TabeL 8 maka, dapat dilihat bahwa nilai rata-rata sesudah penerapan games edukatif berbasis android lebih besar jika dibandingkan sebelum penerapan dengan $\mathrm{t}_{\text {hitung }}=17,86$ dengan nilai probabilitas/sig $\mathrm{t}=0,000$. Karena $\mathrm{p}<0,05$ dan $\mathrm{t}$ hitung lebih besar dari $t_{\text {tabel }}(2,042>17,86)$, maka dapat disimpulkan $\mathrm{H}_{0}$ di tolak dan $\mathrm{H}_{\mathrm{a}}$ diterima. Berarti dapat disimpulkan terdapat perbedaan signifikan antara sebelum menggunakan games edukatif berbasis android (hasil pre-test) dan sesudah menggunakan games tersebut (hasil post-test) pada 30 anak (Responden dari TKN Pembina 1, TKN Pembina 3 dan TK Babussalam, Pekanbaru-Riau). Dapat digambarkan bahwa games edukatif yang diakses secara digital memberikan dukungan yang positif terhadap motivasi belajar, kreativitas dan keterampilan lain yang dibutuhkan anak (Behnamnia et al., 2020). Sejalan dengan pernyataan tersebut maka (Sun, Ruokamo, Siklander, Li, \& Devlin, 2021) menyatakan bahwa games edukatif juga mampu meningkatkan peran serta aktif dan persepsi belajar matematika anak. Keaktifan anak selama proses pembelajaran serta persepsi belajar yang positif akan mendukung hasil belajar yang optimal.

Berdasarkan hasil studi pendahuluan di TK TKN Pembina 1, TKN Pembina 3 dan TK Babussalam, Pekanbaru-Riau ditemukan bahwa kemampuan mengenal angka anak rata-rata masih rendah. Salah satu usaha yang ditempuh untuk meningkatkan kompetensi tersebut adalah dengan penggunaan games edukatif yang dapat diakses guru dan orangtua di Aplikasi Play Store.

Kemampuan mengenal angka merupakan salah satu komponen penting dalam proses pembelajaran di berbagai jenjang pendidikan, salah satunya adalah di PAUD (Adjie, Putri, \& Dewi, 2020). Adapun pendekatan yang dapat digunakan oleh guru maupun orangtua dalam rangka meningkatkan kapabilitas di bidang ini melalui rancangan kegiatan yang sederhana dan mudah ditemui anak dalam aktivitas sehari-hari (Amalina, 2020). Seperti contoh saat anak menghitung jumlah permen kesukaannya, membandingkan jumlah donat yang dimilikinya dengan saudara kandungnya dan sebagainya. Dengan kata lain pengenalan angka bagi anak usia dini merupakan hal yang paling mendasar serta dapat dikemas dalam aktivitas keseharian yang dekat dengan lingkungan anak. 
Hal yang senada juga disampaikan oleh (Duncan et al., 2007) bahwa kemampuan mengenal angka memiliki peran yang strategis dalam meningkatkan kesiapan sekolah anak. Hal ini dikarenakan bahwa salah satu indikator anak siap memasuki Sekolah Dasar adalah mampu mengenal angka dengan baik (Nurhayati, 2018). Berbekal potensi ini, anak dianggap sudah mampu menerima berbagai mata pelajaran seperti halnya matematika dan IPA. Dapat dikatakan dengan kesiapan yang baik ketika memasuki pendidikan dasar maka hal ini akan memberi dukungan pada hasil belajar yang diperolehnya. Jadi dengan kata lain bila anak mampu mencapai kompetensi yang berkaitan dengan angka, maka akan membantunya dalam memperoleh prestasi belajar di sekolah formal. Hal ini tentu akan memberikan manfaat baik bagi anak, guru dan orangtua.

Penguasaan anak terhadap angka juga berkaitan dengan kesejahteraan pada aspek ekonomi ataupun pendapatan anak di masa depannya (Hawes, Nosworthy, Archibald, \& Ansari, 2019). Dengan kata lain rendahnya kompetensi dalam mengenal angka terkait dengan rendahnya literasi sehingga akan berdampak pada penghasilan anak ketika dewasa nanti. Oleh karena itu, menjadi sangat penting membangun pengetahuan dan kemampuan dalam mengenal angka sejak usia dini.

Anak usia dini masa kini disebut sebagai generasi Z. Kelompok usia ini dikenal sangat mudah berinteraksi dengan kemajuan teknologi informasi dalam kehidupan sehari-hari (Chun, Christine, 2017). Seperti mengakses berbagai games menggunakan tablet, merekam video menggunakan smartphone, mengambil gambar menggunakan kamera yang ada pada ponsel pintar dan sebagainya. Games edukatif berbasis android dirancang secara visual dan audio agar anak dapat memperoleh hasil belajar yang optimal di akhir sesi permainan (Suganda, 2016). Orang tua dan guru dapat menggunakan games berbasis aplikasi sebagai media pembelajaran yang menarik bagi anak (Maharani, Nusantara, Rahman, \& Qohar, 2021). Sejalan dengan beberapa uraian sebelumnya maka dapat dideskripsikan bahwa games edukatif yang dikembangkan dalam penelitian ini mampu memberikan dukungan kepada anak dalam meningkatkan kemampuannya di berbagai bidang seperti halnya dalam kemampuan mengenal angka.

\section{SIMPULAN}

Games edukatif berbasis android yang dirancang untuk anak usia 5-6 tahun terbukti memenuhi kriteria dan layak untuk dijadikan sebagai media pengenalan angka. Melalui games yang mendidik, maka anak mendapat kesempatan untuk bermain sambil belajar dengan menggunakan kemajuan teknologi informasi. Selama memainkan permainan ini anak dapat melatih keterampilannya dalam memecahkan masalah sehari-hari melalui cara yang menyenangkan dan sesuai dengan minat dan kebutuhan generasi Z. Games ini juga dapat dijadikan sebagai sumber belajar bagi anak dan media yang fleksibel karena aplikasinya mudah di diakses di aplikasi Play Store. Selanjutnya permainan ini juga dapat dijadikan alternatif media pembelajaran yang efektif bagi anak karena dapat diakses dan dimainkan kapan saja dan dimana saja. Dengan demikian diharapkan games ini mampu memberi kontribusi positif bagi dunia pendidikan anak usia dini.

\section{UCAPAN TERIMA KASIH}

Secara khusus tim peneliti mengucapkan terima kasih kepada FKIP Universitas Riau yang telah memberikan dukungan dalam bentuk dana penelitian.

\section{DAFTAR PUSTAKA}

Adjie, N., Putri, S. U., \& Dewi, F. (2020). Jurnal Obsesi : Jurnal Pendidikan Anak Usia Dini Penerapan Pendidikan Matematika Realistik ( PMR ) dalam Meningkatkan Pemahaman Konsep Bilangan Cacah pada Anak Usia Dini Abstrak. 4(1), 326-337. https:// doi.org/10.31004/obsesi.v4i1.338 
Amalina, A. (2020). Pembelajaran Matematika Anak Usia Dini di Masa Pandemi Covid-19 Tahun 2020. Obsesi, 5(1), 542. https:// doi.org/10.31004/obsesi.v5i1.592

Aunio, P., Korhonen, J., Ragpot, L., Törmänen, M., Mononen, R., \& Henning, E. (2019). Multifactorial approach to early numeracy-The effects of cognitive skills, language factors and kindergarten attendance on early numeracy performance of South African first graders. International Journal of Educational Research, 97(February), 65-76. https://doi.org/10.1016/j.ijer.2019.06.011

Bassok, D., \& Latham, S. (2016). Working Paper : Kids Today : Changes in School-Readiness in an Early Childhood Era. (35).

Behnamnia, N., Kamsin, A., Akmar, M., Ismail, B., \& Hayati, A. (2020). Children and Youth Services Review The e ff ective components of creativity in digital game-based learning among young children : A case study. Children and Youth Services Review, 116(June), 105227. https:/ / doi.org/10.1016/j.childyouth.2020.105227

Chun, Christine, et. al. (2017). Teaching Generation Z at the University of Hawai'i. The IAFOR International Conference on Education - Hawaii 2017 Official Conference Proceedings, 10. Retrieved from https:// papers.iafor.org/submission34202/

Duncan, G. J., Claessens, A., Magnuson, K., Klebanov, P., Pagani, L. S., Feinstein, L., ... Japel, C. (2007). School Readiness and Later Achievement. 43(6), 1428-1446. https://doi.org/10.1037/0012-1649.43.6.1428

Gewati, M. (2018). Kemampuan Matematika Siswa Indonesia Memprihatikan, Solusinya? Artikel ini telah tayang di Kompas.com dengan judul "Kemampuan Matematika Siswa Indonesia Memprihatikan, Solusinya?", Retrieved from https://edukasi.kompas.com/read/2018/03/21/09211381/kemampuan-

matematika-siswa-indonesia-memprihatikan-solusinya

Gutex, G. L. (Ed.). (2013). Metode Montessori. Yogyakarta: Pustaka Pelajar.

Hawes, Z., Nosworthy, N., Archibald, L., \& Ansari, D. (2019). Kindergarten children ' s symbolic number comparison skills predict 1st grade mathematics achievement: Evidence from a two-minute paper-and-pencil test. Learning and Instruction, 59(July 2018), 21-33. https:// doi.org/10.1016/j.learninstruc.2018.09.004

Kementerian Pemberdayaan Perempuan dan Perlindungan Anak. (2019). Profil Anak Indonesia Tahun 2019.

Kementerian Pendidikan dan Kebudayaan. (2018). Penguasaan Materi Ujian Nasional.

Kennedy, L. M., Tipps, S., \& Johnson, A. (2008). Guiding Children's Learning of Mathematics (11th ed.). Belmont: Thomson Higher Education.

Litkowski, E. C., Duncan, R. J., Logan, J. A. R., \& Purpura, D. J. (2020). Journal of Experimental Child When do preschoolers learn specific mathematics skills? Mapping the development of early numeracy knowledge. Journal of Experimental Child Psychology, 195, 104846. https://doi.org/10.1016/j.jecp.2020.104846 https://doi.org/10.1016/j.jecp.2020.104846

Maharani, S., Nusantara, T., Rahman, A., \& Qohar, A. (2021). Jurnal Obsesi : Jurnal Pendidikan Anak Usia Dini Computational Thinking: Media Pembelajaran CSK ( CT- Sheet for Kids ) dalam Matematika PAUD Abstrak. 5(1), 975-984. https://doi.org/10.31004/obsesi.v5i1.769

Mou, Y., Zhang, B., Piazza, M., \& Hyde, D. C. (2021). Early Childhood Research Quarterly Comparing set-to-number and number-to-set measures of cardinal number knowledge in preschool children using latent variable modeling. Early Childhood Research Quarterly, 54, 125-135. https:// doi.org/10.1016/j.ecresq.2020.05.016

Moyer-Packenham, P. S., Lommatsch, C. W., Litster, K., Ashby, J., Bullock, E. K., Roxburgh, A. L., ... Jordan, K. (2019). How design features in digital math games support learning and mathematics connections. Computers in Human Behavior, 91, 316-332. https://doi.org/10.1016/j.chb.2018.09.036 
NCTM. (2000). Executive Summary Principles and Standards for School Mathematics. Retrieved

from https://www.nctm.org/uploadedFiles/Standards_and_Positions/PSSM_ExecutiveS ummary.pdf

Nurhayati, W. (2018). Indonesian Journal of Educational Assessment Pengembangan Instrumen Kesiapan Bersekolah dan Pemetaan Kesiapan Bersekolah Pada Anak Usia Dini di Indonesia The Development of School Readiness Instrument and Mapping School Readiness for Early Childhood Education in Indonesia. 1(1), 11-22. https:// doi.org/10.26499/ijea.v1i1.4

Pei, L., \& Zhang, L. (2019). Games-Based Learning in Future School. In S. Yu, H. Niemi, \& J. Mason (Eds.), Springer. https:// doi.org/10.1007/978-981-13-94393

Pratiwi, I. (2019). Efek Program Pisa Terhadap Kurikulum Di Indonesia. Jurnal Pendidikan Dan Kebudayaan, 4(1), 51. https://doi.org/10.24832/jpnk.v4i1.1157

Ramani, G. B., Daubert, E. N., \& Scalise, N. R. (2019). Role of Play and Games in Building Children ' s Foundational Numerical Knowledge. In Cognitive Foundations for Improving Mathematical Learning (1st ed., Vol. 5). https://doi.org/10.1016/B978-012-815952-1.00003-7

Reys, Robert.E, E. al. (2017). Helping Children Learn Mathematics (2nd ed.). Milton: John Wiley.

Rotem, A., \& Henik, A. (2020). Multiplication facts and number sense in children with mathematics learning disabilities and typical achievers. Cognitive Development, 54(July 2019), 100866. https:/ / doi.org/10.1016/j.cogdev.2020.100866

Setyanti, C. A. (2017). UNESCO: 617 Juta Anak-Remaja Sulit Baca dan Matematika. Retrieved September 22, 2017, from https://www.cnnindonesia.com/gayahidup/20170922085346-282-243265/unesco-617-juta-anak-remaja-sulit-baca-danmatematika

Solfiah, Y. (2018). Kindergarten Teacher ' S Ability In Teaching Math In Tk Pembina Of Pekanbaru City Kemampuan Mengajar Matematika Guru Taman Kanak-Kanak Di Tk Pembina Se-Kota. 1(1), 75-87. https://doi.org/10.24014/kjiece.v1i1.5527

Spaull, N., \& Kotze, J. (2015). International Journal of Educational Development Starting behind and staying behind in South Africa The case of insurmountable learning deficits in mathematics \&. International Journal of Educational Development, 41, 13-24. https:// doi.org/10.1016/j.ijedudev.2015.01.002

Suganda, T. (2016). Pengelolaan Pembelajaran Zaman Now (Generasi Z ). (2), 1-11.

Sugiyono. (2017). Metode Penelitian dan Pengembangan. Bandung: Alfabeta.

Sun, L., Ruokamo, H., Siklander, P., Li, B., \& Devlin, K. (2021). Learning , Culture and Social Interaction Primary school students ' perceptions of scaffolding in digital game- based learning in mathematics. Learning, Culture and Social Interaction, 28(January 2020), 100457. https://doi.org/10.1016/j.lcsi.2020.100457

Tezer, M., \& Cumhur, M. (2016). Anthropological Theory of Didactics and the Probability of the Constructivist Approach Being a Solution to the Common Mistakes Made in Mathematics Lessons. International Journal of Educational Sciences, 15(1-2), 148-156. https:// doi.org/10.1080/09751122.2016.11890524

Tohir, M. (2019). Hasil PISA Indonesia Tahun 2018 Turun Dibanding Tahun 2015. Paper of Matematohir, 2(1), 1-2. https://doi.org/10.31219/osf.io/pcjvx

Vanbecelaere, S., Van den Berghe, K., Cornillie, F., Sasanguie, D., Reynvoet, B., \& Depaepe, F. (2020). The effects of two digital educational games on cognitive and non-cognitive math and reading outcomes. Computers and Education, 143(August 2019), 103680. https:// doi.org/10.1016/j.compedu.2019.103680 